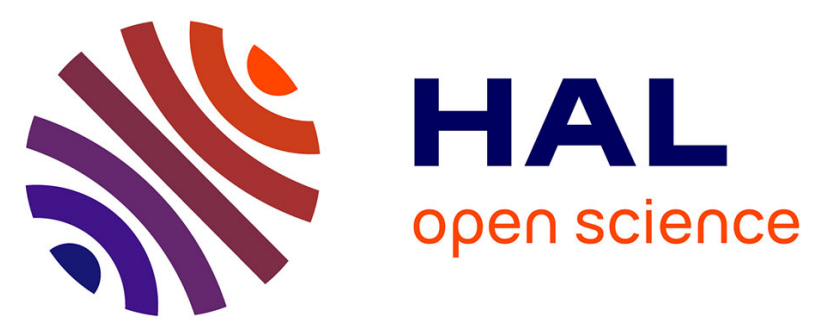

\title{
Variation of fucoid community metabolism during the tidal cycle: Insights from in situ measurements of seasonal carbon fluxes during emersion and immersion
}

François Bordeyne, Aline Migné, Dominique Davoult

\section{- To cite this version:}

François Bordeyne, Aline Migné, Dominique Davoult. Variation of fucoid community metabolism during the tidal cycle: Insights from in situ measurements of seasonal carbon fluxes during emersion and immersion. Limnology and Oceanography, 2017, 10.1002/lno.10574 . hal-03019613

\section{HAL Id: hal-03019613 \\ https://hal.science/hal-03019613}

Submitted on 23 Nov 2020

HAL is a multi-disciplinary open access archive for the deposit and dissemination of scientific research documents, whether they are published or not. The documents may come from teaching and research institutions in France or abroad, or from public or private research centers.
L'archive ouverte pluridisciplinaire HAL, est destinée au dépôt et à la diffusion de documents scientifiques de niveau recherche, publiés ou non, émanant des établissements d'enseignement et de recherche français ou étrangers, des laboratoires publics ou privés. 
1 Title: Variation of fucoid community metabolism during the tidal cycle: insights from in situ

2 measurements of seasonal carbon fluxes during emersion and immersion

3

4 Running head: Intertidal fucoid community metabolism

6 Keywords: Carbon fluxes; Community gross primary production; Community respiration;

7 Emersion; Fucus serratus community; Immersion; In situ metabolism; Intertidal; Seasons;

8 Tidal cycle

9

10 Authors names:

11 François Bordeyne ${ }^{1}$, Aline Migné ${ }^{1}$, Dominique Davoult ${ }^{1}$

Affiliations and addresses:

$14{ }^{1}$ Sorbonne Universités, UPMC Univ Paris 06, CNRS, UMR 7144 AD2M, Station Biologique 15 de Roscoff, 29680 Roscoff, France

Corresponding author: François Bordeyne

Email address: fbordeyne@sb-roscoff.fr

Phone: +33 298292333

Fax number: +33 298292324

\section{ABSTRACT}

Intertidal communities dominated by canopy-forming brown seaweed are typically highly productive systems. However, their metabolism can vary significantly over time, due to fluctuations in abiotic parameters. If tidal and/or seasonal cycles play an important role in the regulation of metabolism in these communities, they may therefore strongly influence community functioning and dynamics. Here, we investigated the low mid-intertidal Fucus serratus community, measuring in situ carbon fluxes of its primary production and respiration during different seasons. To perform direct comparisons of its underwater and aerial metabolism, these measurements were carried out during immersion and emersion, analyzing the changes in dissolved inorganic carbon and in $\mathrm{CO}_{2}$ concentrations under closed benthic chambers. Our results showed that during both emersion and immersion periods, gross community production and community respiration varied seasonally with minimum values in winter and maximum values in summer. These values were, on average, 5 and 3.5 times 
higher when the community was exposed to air than when immersed, due to the large changes that occur in abiotic environmental conditions during the tidal cycle. Primary production fluctuated greatly during immersion and was generally limited by underwater light availability. In contrast, primary production remained high during emersion, partly because canopies limit the water loss of their understory layers. During both tidal periods, community respiration was mainly driven by temperature. Our results suggest that the relatively high metabolism during emersion contributes substantially to the total energy budget of fucoid mid-intertidal communities, even those that are low on the shore and spend most of their time underwater.

\section{INTRODUCTION}

Intertidal communities are by definition exposed to two alternating, contrasting environments (i.e. air and seawater), with markedly different abiotic conditions In these systems, usually composed of both autotrophic and heterotrophic species interacting together, such abrupt changes in abiotic environmental conditions are likely to influence metabolism. For example, changes in light and temperature over tidal cycles have been shown to govern changes in primary production and respiration of seagrass beds (Clavier et al. 2011; Ouisse et al. 2011).

When exposed to air, intertidal primary producers lack nutrient supply and $\mathrm{CO}_{2}$ is their only source of inorganic carbon, while both $\mathrm{HCO}_{3}^{-}$and $\mathrm{CO}_{2}$ are available in seawater. Furthermore, they can undergo numerous stresses (sensu Wahl et al. 2011), such as desiccation (leading to hydric stress) and extreme light intensity and temperature, which are likely to inhibit their photosynthetic efficiency (Quadir et al. 1979; Huppertz et al. 1990; Hanelt et al. 1993) and to active protective mechanisms of strong physiological coasts (Tomanek and Helmuth 2002). Intertidal invertebrates can suffer from emersion as well and are generally sensitive to high temperature and water loss (Raffaelli and Hawkins 1999). Nevertheless, within macroalgal-dominated communities, dense canopy-forming species may buffer these environmental constraints for the understory species (e.g. Tait and Schiel 2013) by lying flat on them, even if this is a source of shading for primary producers.

When immersed in seawater, intertidal primary producers have usually to face low light conditions due to the attenuation of light by seawater, potentially limiting their photosynthesis (Tait and Schiel 2011). However, in this type of complex system, numerous species are able to complement each other, especially for light use (Tait and Schiel 2011). Such complementarity leads those communities to cope efficiently with the harsh environmental conditions they experience throughout a tidal cycle. 
Among intertidal macroalgal communities, those dominated by canopy-forming brown seaweed (Phaeophyta) are particularly ubiquitous in temperate regions (e.g. Lüning 1990; Jueterbock et al. 2013). These complex habitats fulfill some essential ecological roles, including food supply for other habitats and nurseries for numerous invertebrate species (Crawley et al. 2009; Schmidt et al. 2011). Although intertidal macroalgal systems have been recognized as highly productive for several decades (Mann 1973), their metabolism has not been extensively studied to date. Only a few studies have investigated community metabolism in situ, but only either during emersion periods (e.g. Golléty et al. 2008; Bordeyne et al. 2015) or during immersion (e.g. Tait and Schiel 2010), and there are no direct comparisons of aerial and underwater community metabolism (Migné et al. 2015a). However, such comparisons can provide insight into the relationship between environmental constraints and community metabolism (Pedersen et al. 2013), and therefore into the functioning and dynamics of such communities.

Here, we investigated the large intertidal community dominated by Fucus serratus Linnaeus. Its aerial and underwater rates of gross production and respiration were compared by measuring in situ carbon fluxes both during emersion and immersion. This comparison was carried out at different periods of the year to study the effect of the seasonal variations in environmental parameters (Rheuban et al. 2014). Light intensity and temperature were also surveyed in an attempt to determine their role in the regulation of community metabolism. Because the F. serratus community is established at the low mid-intertidal level, it is exposed to air for only approximately 15 to $25 \%$ of time. We tested whether this community exhibits higher primary production during immersion than during emersion.

\section{MATERIALS AND METHODS}

\section{Study site}

This study was performed on an intertidal boulder reef located in front of the Station Biologique de Roscoff $\left(48^{\circ} 43.778^{\prime} \mathrm{N}, 3^{\circ} 59.770^{\prime} \mathrm{W}\right)$ in the southwestern part of the English Channel. This reef is located in the temperate part of the Northern hemisphere and therefore has seasonal variations in incident irradiance and temperature (Supplementary material 1). This semi-sheltered reef experiences a semi-diurnal tidal cycle with maximal amplitude of about $9 \mathrm{~m}$. Several communities dominated by canopy-forming algae are established on this shore according to a vertical zonation pattern. The low mid-intertidal level of this shore (from 2.5 to $3.5 \mathrm{~m}$ above chart datum) is typically characterized by a dense belt of the F. serratus community, where the thallus of the dominant species frequently covers $100 \%$ of the 
substratum, and is associated with miscellaneous epibionts (i.e. algae and sessile invertebrates directly attached to the Fucus thallus; see Wahl 2009) and biofilms. This community is also composed of numerous sub-canopy and encrusting algae, and supports a diverse pool of mobile invertebrates (Migné et al. 2015b).

\section{Measurement of community metabolism}

Within this area, three quadrats were built on the rock with concrete so that they were representative of the community, containing one to several $F$. serratus thalli (about $25 \mathrm{~cm}$ long), understory and encrusting algae as well as invertebrates (Fig 1a, see Supplementary material $2 \& 3$ for more details on community diversity). They were set 2-3 m apart and their internal surface area was of ca. $0.07 \mathrm{~m}^{2}(26.5 \mathrm{~cm} \times 26.5 \mathrm{~cm})$. Community respiration $(\mathrm{CR}$, i.e. which includes both the autotrophic and heterotrophic components, Gattuso et al. 1998) and net community production ( $\mathrm{NCP}$, i.e. the balance between gross primary production and $\mathrm{CR}$ ) were examined using short incubations under a benthic chamber performed in darkness and in ambient light, respectively, during emersion and immersion. To do so, custom-built incubation chambers made of opaque (for CR measurements) or clear (for NCP measurements) Plexiglas were set down on the concrete quadrats (total volume of ca. 20L) and secured using elastic straps (Fig $1 \mathrm{~b} \& \mathrm{c}$ ). It was assumed that respiration rates measured in darkness after an abrupt transition from ambient light reflect the respiration activity of the community (del Giorgio and Williams 2005; Tait and Schiel 2013).

For immersion measurements, incubation chambers were placed on the concrete quadrats by scuba divers, ensuring that no air bubbles remained inside. Mixing of seawater within the chambers was ensured by autonomous stirrers. Using $100 \mathrm{~mL}$ syringes, seawater samples were collected from inside the chambers at the beginning and the end of incubations to estimate changes in dissolved inorganic carbon (DIC). $\mathrm{pH}$ and temperature of these samples were measured immediately using a $\mathrm{pH}$ meter (HQ40d portable $\mathrm{pH}, \mathrm{Hach} \circledast$, Loveland, $\mathrm{CO}$, USA) coupled with a pH electrode (IntellicalTM PHC101 standard gel filled electrode, Hach®). Samples were then filtered through cellulose acetate filters $(0.8 \mu \mathrm{m})$ and poisoned with $\mathrm{HgCl}_{2}$. In the laboratory, total alkalinity of each sample was determined on three $20 \mathrm{~mL}$ subsamples using $0.01 \mathrm{~N} \mathrm{HCl}$ potentiometric titration with an automatic titrator (Titroline alpha, Schott SI Analytics, Mainz, Germany). DIC was calculated from temperature, salinity, $\mathrm{pH}$ and total alkalinity using $\mathrm{CO}_{2} \mathrm{SYS}$ software (Lewis et al. 1998) with the constants from Mehrbach et al. (1973) refitted by Dickson and Millero (1987). Inorganic carbon fluxes were then calculated from the difference between the final and initial DIC concentrations. 
137 For emersion measurements, the chambers were connected to infrared $\mathrm{CO}_{2}$ gas analyzers $(\mathrm{Li}-$ 138 Cor Li820, LI-COR®, Lincoln, Nebraska, USA), to form closed air-circuits, where an air circulation rate of $1 \mathrm{~L} \mathrm{~min}^{-1}$ was ensured by pumps (Fig 1c). $\mathrm{CO}_{2}$ concentration $\left(\mu \mathrm{mol}_{\mathrm{CO} 2}\right.$ mol $_{\text {air }}{ }^{-1}$ ) within the chambers was recorded every $5 \mathrm{~s}$. These data were then used to determine carbon fluxes during each incubation $\left(\mathrm{mg} \mathrm{C} \mathrm{h}^{-1}\right)$, assuming a molar volume of $22.4 \mathrm{~L} \mathrm{~mol}^{-1}$ at standard pressure and temperature, and a molar mass of $12 \mathrm{~g} \mathrm{C} \operatorname{mol}_{\mathrm{CO} 2}{ }^{-1}$, as described by

143 Migné et al. (2002).

144 The underwater and aerial metabolism of the $F$. serratus community was measured on 13 145 occasions from April 2014 to February 2016. Underwater measurements were always carried 146 out around midday, during the rising tide of neap tide, and consisted of the succession of one 147 dark incubation and one light incubation, performed simultaneously on the three quadrats 148 (only two in November 2014). Dark and light incubations were performed respectively at a 149 mean depth of $2.4 \pm 1.0 \mathrm{~m}$ and $3.0 \pm 0.6 \mathrm{~m}$, and were carried out for ca. 20 to $75 \mathrm{~min}$, 150 according to the seasonal variation of seawater temperature (i.e. duration of incubations 151 decreased as seawater temperature increased). Measurements during emersion were always carried out during the following spring tide, a few days later. At each occasion and for each of the three quadrats, three light incubations (only two in November 2014) and a dark incubation were performed successively. These incubations were always carried out from the onset of the emersion period (around midday) to prevent desiccation which may affect both GCP and CR. As well, these incubations were sufficiently short (ca. 3 to $5 \mathrm{~min}$ ) to avoid that changes in temperature and $\mathrm{CO}_{2}$ concentration within the chambers affect metabolic rates. When necessary (i.e. when $F$. serratus thalli overstepped quadrat limits), $F$. serratus thalli were gently moved within the quadrats, taking care to preserve a community structure similar as the one observed in situ.

161 At the end of each incubation, benthic chambers were opened to allow complete seawater or air replenishment before the beginning of a new incubation. Metabolic rates were calculated according to the internal surface area of the concrete quadrats and expressed in carbon units

164 for the community $\left(\mathrm{mg} \mathrm{C} \mathrm{m} \mathrm{m}^{-2} \mathrm{~h}^{-1}\right.$ ). During emersion and immersion, $\mathrm{NCP}$ and $\mathrm{CR}$ 165 measurements were used to calculate the gross community production (GCP), as $\mathrm{GCP}=\mathrm{NCP}$ $166+\mathrm{CR}$. The ratio of CR to GCP was also calculated for each set of measurements (except when GCP was equal to 0 ). In addition, a series of four underwater incubations were performed in ambient light (hereafter referred to as "underwater incubation series") in July 2014 to measure the variation of NCP over an immersion period (approx. 80, 145, 240 and 290 minutes after the rising tide flooded 
171 the quadrats, corresponding to a seawater height above the quadrats of approx. 1.6, 3.0, 4.1 172 and $4.5 \mathrm{~m}$, respectively). The variation of GCP was then evaluated by using the CR 173 previously obtained for each quadrat, considering that it was representative of the month of measurement and remained constant over the immersion period.

175 Likewise, the metabolism of the $F$. serratus community was studied during entire emersion 176 periods of spring tide (hereafter referred to as "aerial incubation series"), on haphazardly 177 selected areas of $0.09 \mathrm{~m}^{2}(30 \mathrm{~cm} \times 30 \mathrm{~cm})$ containing one to several $F$. serratus thalli and 178 their associated community. Seven aerial incubation series were performed from April 2014 to April 2015. At each occasion, successive sets of light and dark incubations were carried out from the onset of the emersion period to the return of seawater at intervals of ca. 25 to $40 \mathrm{~min}$. The first set was used as a reference for community metabolism without any desiccation, and the following GCP and CR measurements were expressed as a percentage of these first values. At the end of the incubation series, the canopies were sampled to estimate the degree of desiccation they experienced during emersion. To do so, canopies were weighed a few minutes after removal $\left(\mathrm{FW}_{\text {end }}\right)$. They were then immersed in seawater overnight to fully recover their water content, and weighed the following day $\left(\mathrm{FW}_{\text {full }}\right)$. Finally, canopies were dried $\left(60^{\circ} \mathrm{C}, 48 \mathrm{~h}\right)$ and weighed (DW). Loss of water at the end of emersion period was estimated according to the following equation:

$$
\text { Water loss }(\%)=\left(1-\frac{\text { FWend }- \text { DW }}{\text { FWfull }- \text { DW }}\right) \times 100
$$

190 During all incubations, temperature and irradiance (PAR, $400-700 \mathrm{~nm}$ ) were measured close to the incubation chambers. Temperature was recorded every 5 min using HOBO $®$ Pendant ${ }^{\circledR}$ Temperature/Light data loggers (Onset Computer Corporation, Bourne, MA, USA). During underwater incubations, irradiance was recorded every minute in seawater using a spherical sensor (ultra-miniature MDS-MKV), while during emersion incubations, incident irradiance (i.e. in the air) was recorded every minute using a planar sensor (Li-Cor QuantumSA-190). For the underwater incubation series, irradiance was recorded simultaneously in seawater (ultra-miniature MDS-MKV) and in the air (Quantum sensor SKP215, Skye Instruments, sensor located on the Station Biologique de Roscoff, approx. $700 \mathrm{~m}$ of our study site). As well, simultaneous spherical and planar (Compact-LW ALW-CMP sensor, JFE Advantech Co., Ltd., Hyogo, Japan) sensor measurements were used to calculate a conversion factor $\left(0.746, R^{2}=0.937, n=877, p<0.001\right)$ for underwater irradiance. 
204 The 13 means of GCP, CR and CR:GCP ratio measured in the fixed quadrats (i.e. those made with concrete) were compiled over a calendar year according to the day of measurement, for emersion and immersion separately. Sinusoidal curves were then fitted to these values to demonstrate seasonal patterns, according to the following equation:

$$
\mathrm{y}=a+\mathrm{b} \sin \left(\frac{2 \pi}{365} x+c\right)
$$

where $\mathrm{y}$ is the predicted value of the considered variable, and $\mathrm{x}$ is the time in days. The $\mathrm{a}, \mathrm{b}$ and c parameters represent respectively the theoretical year-round average, the theoretical year-round amplitude and the phase at origin for the considered variable. For GCP during immersion, the model was constrained in such a way that a and b were equal, to avoid negative predicted values. An $F$-test was used to test the fit, using $\mathrm{R}$ software, version 3.2.2

213 (R Core Team 2015). Comparisons between emersion and immersion values of GCP, CR,

214 CR:GCP ratio, incident irradiance, and temperature during both light and dark incubations were performed using Wilcoxon signed rank tests on the mean values from each set of measurements.

217 Correlation between CR values and temperature during dark incubations was tested using 218 Pearson's coefficient, for emersion and immersion separately.

219 GCP values obtained during emersion and immersion, as well as those of the underwater 220 incubations series, were pooled and plotted against the mean irradiance measured during these 221 incubations. A photosynthesis versus light curve (P-I curve) was then fitted to these values, according to the mathematical model of Webb et al. (1974) chosen due to the absence of 223 photoinhibition:

$$
\mathrm{GCP}=\operatorname{GCPmax}\left(1-\mathrm{e}^{\left(-\frac{\mathrm{I}}{\mathrm{Ik}}\right)}\right)
$$

where GCP is the observed gross primary production, $\mathrm{GCP}_{\max }$ is the theoretical maximal gross primary production, $I$ is the irradiance during light incubations and $I_{k}$ is the irradiance at which $\mathrm{GCP}_{\max }$ would be reached if GCP had continued to increase in a linear way with increasing PAR. An $F$-test was used to test the fit.

228 Regarding the aerial incubation series, a two-degree polynomial curve was fitted to the GCP values according to the duration of aerial exposure, and relationship was tested using an $F$ test. The linear relationship between $\mathrm{CR}$ and duration of exposure was also tested using an $F$ test. 
234 During immersion, the community GCP (mean $\pm \mathrm{SE}$ ) ranged from 0 to $962.2 \pm 430.4 \mathrm{mg} \mathrm{C}$ $235 \mathrm{~m}^{-2} \mathrm{~h}^{-1}$ and CR (mean $\pm \mathrm{SE}$ ) from $19.5 \pm 5.4$ to $266.4 \pm 84.5 \mathrm{mg} \mathrm{C} \mathrm{m}^{-2} \mathrm{~h}^{-1}$ (Fig 2a). During emersion, the $F$. serratus community GCP ranged from $620.0 \pm 36.5$ to $1515.5 \pm 478.3 \mathrm{mg} \mathrm{C}$ $\mathrm{m}^{-2} \mathrm{~h}^{-1}$ and CR from $95.0 \pm 41.0$ to $685.5 \pm 398.1 \mathrm{mg} \mathrm{C} \mathrm{m}^{-2} \mathrm{~h}^{-1}$ (Fig 2b). GCP and CR displayed seasonal patterns that showed significant fit with sinusoidal curves, reaching their maximum values during summer and their minimum values during winter, for both emersion and immersion measurements (Fig 2a \& 2b, Table 1). GCP and CR values were significantly higher during emersion than during immersion (Table 2), being on average 5 and 3.5 times higher when the community was exposed to the air, respectively. Likewise, irradiance and temperature recorded during the incubations also showed strong seasonal changes (Fig 2c \& 2d) and were significantly higher during emersion than during immersion (Table 2). The CR:GCP ratio ranged from 0.10 to 0.75 (Fig 3). It showed a seasonal pattern that fitted significantly with a sinusoidal curve (Table 1) during emersion but not during immersion $\left(F_{3,9}, p>0.05\right)$. This CR:GCP ratio did not show any significant differences between emersion and immersion (Wilcoxon signed rank test, $p>0.05$ ).

During the underwater incubation series, GCP decreased gradually for the first three incubations (approx. 80, 145 and 240 minutes after the rising tide flooded the quadrats) and increased for the last one (approx. 290 minutes after the rising tide flooded the quadrats) (Fig 4). Incident irradiance (i.e. in the air) remained stable for the first three incubations, while underwater irradiance decreased gradually, mainly due to a rise in seawater level above the benthic chambers (seawater height above the quadrats of approx. 1.6, 3.0 and $4.1 \mathrm{~m}$ ). Finally, increases in incident and underwater irradiances were observed for the last incubation (approx. $4.5 \mathrm{~m}$ of seawater above the quadrats), and resulted primarily from changes in cloud cover (Fig 4). Based on all the data points for mean GCP versus irradiance, the P-I curve showed significant fit with the Webb et al. (1974) model (Fig $5, F_{2,28}, R^{2}=0.916, p<0.001$ ), with a $\mathrm{GCP}_{\max }$ of $1310.7 \mathrm{mg} \mathrm{C} \mathrm{m}^{-2} \mathrm{~h}^{-1}$ and an $\mathrm{I}_{\mathrm{k}}$ of $696 \mu \mathrm{mol}$ photons $\mathrm{m}^{-2} \mathrm{~s}^{-1}$. CR was significantly correlated with the temperature recorded during dark incubations, for emersion (Fig 6, $F_{1,11}, R^{2}=0.688, p<0.001$ ) and immersion (Fig 6, $F_{1,11}, R^{2}=0.462, p=0.010$ ).

During the aerial incubation series, GPP increased slightly for the first $70 \mathrm{~min}$ and then decreased reaching approx. $80 \%$ of initial GPP after more than 200 min of emersion (Fig 7a, $\left.F_{3,114}, R^{2}=0.327, p<0.001\right)$. In contrast, CR decreased continuously from the onset of emersion reaching approx. $75 \%$ of initial CR after more than 200 min of emersion (Fig $7 \mathrm{~b}$, $\left.F_{1,115}, R^{2}=0.296, p<0.001\right)$. The canopies lost on average $18.7 \pm 4.4 \%$ of their water content at the end of the emersion period. 


\section{DISCUSSION}

270 To our knowledge, this study is the first one to investigate the in situ metabolism of an intertidal macroalgal community, during both emersion and immersion, and throughout the year. Results highlighted that the $F$. serratus community displayed, during both tidal periods, high rates of primary production and respiration that fluctuated throughout the year according to a seasonal pattern well-established for such communities in temperate areas (e.g. Cheshire et al. 1996; Golléty et al. 2008; Bordeyne et al. 2015). Accordingly, either when exposed to the air or immersed in seawater, the metabolism of this community was at its highest in summer, when both light availability and temperature were at their highest annual levels, and at its lowest in winter. This pattern confirms that the dynamics of community metabolism respond to the year-round fluctuations of climatic conditions, with light availability and temperature constituting the main drivers of GCP and CR, respectively (Davison 1991; Kemp and Testa 2011; Tait and Schiel 2013). The CR:GCP ratio also showed a significant seasonal trend when calculated from measurements during emersion. The values of this ratio and its seasonal trend are in agreement with those previously observed for the same community (Bordeyne et al. 2015), indicating that the underlying processes are highly conserved from year to year. The ratio between gross community production and community respiration may thus depend on the combination of the seasonal fluctuations of two main elements: algal biomass and temperature. The summertime increase in biomass usually leads to changes in community structure, which are characterized by an increase in self-shading, limiting primary production (Binzer and Sand-Jensen 2002a; b). Furthermore, the summertime rise in temperature increases the respiration rate of whole community (including autotrophic and heterotrophic organisms) more strongly than gross community production rate of autotrophic organisms (López-Urrutia et al. 2006; Tait and Schiel 2013). However, no seasonal trends in the CR:GCP ratio were detected from immersion measurements. Some autumn and winter values of the CR:GCP ratio at immersion were rather high compared to values at emersion. This ensues from the extremely low values of GCP measured underwater. At these periods of the year, the low light environment experienced underwater could lead to a community acting as a heterotrophic system at immersion (i.e. CR > GCP, as observed in January when GCP = $0)$. Both primary production and respiration rates of the F. serratus community were significantly higher during emersion than during immersion. Numerous studies have attempted to describe how intertidal macroalgae living at various shore levels respond to the 
therein). Some studies illustrate that upper-shore species exhibit greater photosynthetic capacities or primary production in air than in water, contrary to lower-shore species (e.g. Johnson et al. 1974; Quadir et al. 1979; Migné et al. 2015a). However, these studies are carried out either on small fragments of algae or on entire individuals, but not on whole communities. The environmental constraints that fragments or individuals experience may, however, greatly differ from those experienced by whole communities with structural complexity (see Pedersen et al. 2013 and references therein). Such systems also show higher physiological performance when intact due to the degree of complementarity between layers and/or species (e.g. Tait and Schiel 2011). For instance, sub-canopy (e.g. Mastocarpus stellatus, Cladophora rupestris) or encrusting (e.g. Hildenbrandia rubra, Phymatolithon lenormandii) algae might contibute significantly to the gross community production by benefitting from incident light unused by the dominant species (Tait and Schiel 2011; Tait et al. 2014). Community complexity is therefore of critical importance and the complementarity observed between layers and/or species may even be amplified when these complex systems are exposed to air. Indeed, isolated algae usually suffer from desiccation and/or high solar radiation when exposed to air, potentially affecting their physiology (e.g. Williams and Dethier 2005; Lamote et al. 2012). In a multilayered community, the upper layer acts as a natural filter, protecting the other layers of the community from desiccation, extreme light and high temperature, thereby facilitating metabolic activity. For instance, at the end of emersion periods during which the aerial incubation series were performed, the upper layer was almost dried out whereas the lower understory remained moist, limiting the total water loss for the canopies (less than $20 \%$ ), and more generally for whole communities. These observations are in accordance with those reported for an intertidal Fucus gardneri population (Haring et al. 2002). Interestingly, during our aerial incubation series, the GCP slightly increased during the first tens of minutes, as already observed for some intertidal canopy-forming algae (Brinkhuis et al. 1976; Quadir et al. 1979; Madsen and Maberly 1990). Such observation has usually been attributed to the removal of the surface layer of water on algal thallus, which causes a decrease in the diffusive resistance of atmospheric $\mathrm{CO}_{2}$. Therefore, this extracellular water loss appeared to be beneficial for whole community metabolism. After these first tens of minutes, a trend in decreasing GCP was observed until the end of emersion periods. This decrease could result from an intracellular dehydration of algal thallus (and especially of the upper $F$. serratus layer). These results suggest therefore that both photosynthetic and respiratory processes, when considered at the community scale, are water-dependent. 
336 During this study, photoinhibition was also avoided at the community scale, as shown by the 337 P-I curve. This is especially noticeable during emersion periods, when extreme light intensities reached the community, but where the upper layer of the canopy acted as a sunlight protection. In these conditions, a high rate of gross community production was maintained throughout emersion periods, regardless of the time of the year, even though the light distribution for the understory layers was probably uneven and sub-optimal (Binzer and SandJensen 2002b). Therefore, from an ecological point of view, aerial exposure constitutes a favorable environment for primary production of this type of intertidal community due to the canopy effect and to a significant complementarity between layers and species. For practical reasons, underwater light incubations began on average $140 \mathrm{~min}$ after tidal flooding, when benthic chambers were submerged under on average $3.0 \mathrm{~m}$ of seawater. These conditions are not optimal for the photosynthesis in the $F$. serratus community because light intensity is significantly attenuated by seawater. Thus, GCP is probably higher a few minutes just after tidal flooding, when the underwater light level is maximal. The large changes in GCP measured during the underwater incubation series are consistent with the fluctuation in underwater light availability. However, it would be interesting to reproduce such measurements on different seasons, as underwater light regimes might display substantial seasonal changes (Anthony et al. 2004; Desmond et al. 2015). Gross community production appears therefore to be a highly fluctuating process when underwater, due to the continuous and rapid changes in light intensity caused by ebbing and rising tides, as suggested by Dring and Lüning (1994). This was already shown at the community scale in seagrass beds (Ouisse et al. 2011), confirming confirming the observations made in situ on Laminariales, at the thallus (Gévaert et al. 2003) or individual scale (Delebecq et al. 2013).

Higher rates of primary production observed during emersion than during immersion are likely due to the higher light intensity reaching the community. These results challenge however those obtained for intertidal macrophyte-dominated systems in which light distribution is assumed to be more favorable underwater (Clavier et al. 2011; Ouisse et al. 2011). Ouisse et al. (2011) explained partly their results by a systematical superimposition of leaves from the same root during emersion periods, which generates a significant self-shading for Zostera species. This confirms that the complex structure of intertidal communities is of critical importance when investigating their metabolism (Tait and Schiel 2011).

A significant P-I curve was fitted on all data points for GCP versus irradiance (i.e. for both emersion and immersion). An annual $\mathrm{I}_{\mathrm{k}}$ of nearly $700 \mu \mathrm{mol}$ photons $\mathrm{m}^{-2} \mathrm{~s}^{-1}$ was calculated for 
submerged macrophyte communities (i.e. $5-95^{\text {th }}$ percentiles were $203-795 \mu$ mol photons $\mathrm{m}^{-2} \mathrm{~s}^{-}$

$371^{1}$, Binzer et al. 2006), but substantially higher than those obtained for the mid-intertidal 372 Ascophyllum nodosum community when exposed to air (i.e. $192 \pm 156 \mu$ mol photons $\mathrm{m}^{-2} \mathrm{~s}^{-1}$, 373 Golléty 2008). The P-I curve also shows that GCP did not reach saturation, even under maximal irradiance. This lack of saturation has already been demonstrated on other natural macroalgal assemblages using underwater incubations (e.g. Middelboe et al. 2006; Tait and Schiel 2011), and results from sub-optimal light distribution among assemblage layers. The primary production of the $F$. serratus community is thus mainly regulated by light availability, regardless of the time of year and the tidal period. Its metabolism is efficient in aerial and underwater environments, providing that there is sufficient light. Light is however often considered as one of the most variable abiotic components of coastal shores (Schubert et al. 2001), being driven, among others, by pattern of clouds formation, seawater turbidity or tidal regime (Anthony et al. 2004). Further investigations are needed to better understand the regulation of primary production in intertidal fucoid communities, especially when exposed to extreme environmental conditions that were not encountered during this study, such as low light environments when exposed to air and, conversely, to high light environments when underwater.

The respiration of the $F$. serratus community was mainly driven by temperature, as indicated by the highly significant correlations between CR and temperature during dark incubations. This pattern is in agreement with the general opinion that temperature has a strong effect on respiration rates (Kemp and Testa 2011; Tait and Schiel 2013). However, in winter, when seawater temperature was higher than air temperature, $\mathrm{CR}$ was higher when the community was exposed to air than when underwater. Although this observation does not challenge the general conclusion on the dynamics of community metabolism, there appears to be a slight difference in respiration activity during emersion and immersion. This difference may be related to the physiological activity of epibiotic and heterotrophic microorganisms. It is now widely accepted that macroalgae, and Fucus species in particular, are associated with a wide variety of epibiotic microorganisms (e.g. Stratil et al. 2013; Saha and Wahl 2013). These microorganisms may depend on the release of algal exopolymer substances (EPS). When algae are exposed to the air, EPS remain on the fronds, constituting an important source of energy for heterotrophic microorganisms (Wyatt et al. 2010, 2014), and leading to enhanced community respiration (Golléty et al. 2008; Golléty and Crowe 2013). However, when the algae are immersed, the EPS are released in the surrounding seawater, as dissolved organic carbon, and rapidly removed by water motion. 
Overall, this study highlights that air is not the least favorable environment for primary production in intertidal macroalgae communities. Emersion periods may thus substantially contribute to the annual carbon budget of the $F$. serratus community. For instance, light intensities during underwater incubations rarely reached the $\mathrm{I}_{\mathrm{k}}$ determined during this study, indicating that GCP was generally light-limited during an immersion period. Our results complement those of Middelboe et al. (2006), which demonstrated that shallow-water macroalgal communities are strongly light-limited during most of the year (see also Pedersen et al. 2013 and references therein). Emersion periods are thus essential for the organic carbon requirements of photosynthetic organisms, especially in winter when intertidal communities rapidly encounter a low-light environment with the rising of the tide. Without these periods of air exposure, intertidal algae in temperate regions would completely drain their organic carbon stocks (Bordeyne et al. 2015). Thus, while Maberly and Madsen (1990) calculated that emersion periods can substantially contribute to the overall energy budget of a single species inhabiting high shore levels (i.e. Fucus spiralis), our results support the idea that they can also substantially contribute to the energy budget of whole intertidal communities, even those spending most of their time underwater.

This study falls in with previous investigations which have as common purpose to improve our understanding of the in situ metabolism of intertidal macroalgae communities (e.g. Golléty et al. 2008; Tait and Schiel 2011; Bordeyne et al. 2015). For the first time, a comparison between aerial and underwater CR and GCP has been performed for such community. For practical reasons, however, our incubations may have not completely recreated the full range of conditions to which the F. serratus community is exposed over a year. It would therefore be interesting to develop for the future a flexible chamber for underwater incubations, in such a way that the community stays subjected to natural water movement (rather than the one induced by autonomous stirrer). As well, and despite the complexity imposed by intertidal habitats, some efforts should be given to make continuous metabolism measurement on dense macroalgal communities, using a non-invasive system, as performed for subtidal (e.g. Falter et al. 2008; Long et al. 2013; Rheuban et al. 2014) or terrestrial habitats (e.g. Goulden et al. 2011). Through these future steps, understanding of intertidal community functioning would potentially be improved at a thinner time scale.

\section{CONCLUSION}

436 By analyzing carbon fluxes of the $F$. serratus community at different seasons and during 437 emersion and immersion periods, we highlight the main drivers of community metabolism. 
438 Primary production was mainly driven by light availability whether the community was 439 exposed to air or underwater, and respiration was mainly driven by temperature, with a slight 440 difference between the two tidal periods. This study also demonstrated that the community 441 maintains high rates of primary production throughout an emersion period, despite potentially 442 high stress levels. Emersion periods thus appear to contribute substantially to the annual 443 carbon budget of this type of intertidal community. The next step is to determine a realistic 444 and accurate annual carbon budget for this community, using a modelling approach based on 445 the present metabolism measurements. 
REFERENCES

Anthony, K. R. N., P. V. Ridd, A. R. Orpin, P. Larcombe, and J. Lough. 2004. Temporal variation of light availability in coastal benthic habitats: effects of clouds, turbidity, and tides. Limnol. Oceanogr. 49: 2201-2211.

Binzer, T., and K. Sand-Jensen. 2002a. Production in aquatic macrophyte communities: a theoretical and empirical study of the influence of spatial light distribution. Limnol. Oceanogr. 47: 1742-1750.

Binzer, T., and K. Sand-Jensen. 2002b. Importance of structure and density of macroalgae communities (Fucus serratus) for photosynthetic production and light utilisation. Mar. Ecol. Prog. Ser. 235: 53-62. doi:10.3354/meps235053

Binzer, T., K. Sand-Jensen, and A.-L. Middelboe. 2006. Community photosynthesis of aquatic macrophytes. Limnol. Oceanogr. 51: 2722-2733. doi:10.2307/4499651

Bracken, M. E. S., and J. J. Stachowicz. 2006. Seaweed diversity enhances nitrogen uptake via complementary use of nitrate and ammonium. Ecology 87: 2397-2403.

Brinkhuis, B. H., N. R. Tempel, and R. F. Jones. 1976. Photosynthesis and respiration of exposed salt-marsh fucoids. Mar. Biol. 34: 349-359. doi:10.1007/BF00398128

Bordeyne, F., A. Migné, and D. Davoult. 2015. Metabolic activity of intertidal Fucus spp. communities: evidence for high aerial carbon fluxes displaying seasonal variability. Mar. Biol. 162: 2119-2129. doi:10.1007/s00227-015-2741-6

Cheshire, A. C., G. Westphalen, A. Wenden, L. J. Scriven, and B. C. Rowland. 1996. Photosynthesis and respiration of phaeophycean-dominated macroalgal communities in summer and winter. Aquat. Bot. 55: 159-170. doi:10.1016/S0304-3770(96)01071-6

Clavier, J., L. Chauvaud, A. Carlier, E. Amice, M. Van der Geest, P. Labrosse, A. Diagne, and C. Hily. 2011. Aerial and underwater carbon metabolism of a Zostera noltii seagrass bed in the Banc d'Arguin, Mauritania. Aquat. Bot. 95: 24-30. doi:10.1016/j.aquabot.2011.03.005

Crawley, K., G. Hyndes, M. Vanderklift, A. Revill, and P. Nichols. 2009. Allochthonous brown algae are the primary food source for consumers in a temperate, coastal environment. Mar. Ecol. Prog. Ser. 376: 33-44. doi:10.3354/meps07810

Davison, I. R. 1991. Environmental effects on algal photosynthesis: Temperature. J. Phycol. 27: 2-8. doi:10.1111/j.0022-3646.1991.00002.x

Delebecq, G., D. Davoult, D. menu, M.-A. Janquin, J.-C. Dauvin, and F. Gévaert. 2013. Influence of local environmental conditions on the seasonal acclimation process and 
the daily integrated production rates of Laminaria digitata (Phaophyta) in the English Channel. Mar. Biol. 160: 503-517. doi:10.1007/s00227-012-2106-3

Desmond, M. J., D. W. Pritchard, and C. D. Hepburn. 2015. Light limitation within Southern New Zealand kelp forest communities. PLoS ONE 10: e0123676. doi:10.1371/journal.pone.0123676

Dethier, M. N., and S. L. Williams. 2009. Seasonal stresses shift optimal intertidal algal habitats. Mar. Biol. 156: 555-567. doi:10.1007/s00227-008-1107-8

Dickson, A. G., and F. J. Millero. 1987. A comparison of the equilibrium constants for the dissociation of carbonic acid in seawater media. Deep Sea Res. Part Oceanogr. Res. Pap. 34: 1733-1743. doi:10.1016/0198-0149(87)90021-5

Dring, M. J., and K. Lüning. 1994. Influence of spring-neap tidal cycles on the light available for photosynthesis by benthic marine plants. Mar. Ecol. Prog. Ser. 104: 131-137.

Falter, J. L., R. J. Lowe, M. J. Atkinson, S. G. Monismith, and D. W. Schar. 2008. Continuous measurements of net production over a shallow reef community using a modified Eularian approach. J. Geophys. Res. 113: C07035.

Gattuso, J. P., M. Frankignoulle, and R. Wollast. 1998. Carbon and carbonate metabolism in coastal aquatic ecosystems. Annu. Rev. Ecol. Syst. 29: 405-434. doi: 10.1146/annurev.ecolsys.29.1.405

Gévaert, F., A. Créach, D. Davoult, A. Migné, G. Levavasseur, P. Arzel, A.-C. Holl, and Y. Lemoine. 2003. Laminaria saccharina photosynthesis measured in situ: photoinhibition and xanthophyll cycle during a tidal cycle. Mar. Ecol. Prog. Ser. 247: 43-50.

del Giorgio, P. A., and P. J. le B. Williams. 2005. Respiration in aquatic ecosystems, Oxford Univ. Press.

Golléty, C. 2008. Fonctionnement (métabolisme et réseau trophique) d'un système intertidal rocheux abrité, la zone à Ascophyllum nodosum, relation avec la biodiversité algale et animale. Ph-D thesis, UPMC Univ paris 6, 170 p.+ 4 annexes.

Golléty, C., and T. Crowe. 2013. Contribution of biofilm to ecosystem functioning in rock pools with different macroalgal assemblages. Mar. Ecol. Prog. Ser. 482: 69-79. doi:10.3354/meps 10238

Golléty, C., A. Migné, and D. Davoult. 2008. Benthic metabolism on a sheltered rocky shore: role of the canopy in the carbon budget. J. Phycol. 44: 1146-1153. doi:10.1111/j.1529-8817.2008.00569.x 
Goulden, M. L., A. M. S. McMillan, G. C. Winston, A. V. Rocha, K. L. Manies, J. W. Harden, and B. P. Bond-Lamberty. 2011. Patterns of NPP, GPP, respiration, and NEP during boreal forest succession. Glob. Change Biol. 17:855-871. doi:10.1111/j.13652486.2010.02274.x

Hanelt, D., K. Huppertz, and W. Nultsch. 1993. Daily course of photosynthesis and photoinhibition in marine macroalgae investigated in the laboratory and field. Mar. Ecol. Prog. Ser. 97: 31-37. doi:10.3354/meps097031

Haring, R., M. Dethier, and S. Williams. 2002. Desiccation facilitates wave-induced mortality of the intertidal alga Fucus gardneri. Mar. Ecol. Prog. Ser. 232: 75-82. doi:10.3354/meps 232075

Huppertz, K., D. Hanelt, and W. Nultsch. 1990. Photoinhibition of photosynthesis in the marine brown alga Fucus serratus as studied in field experiments. Mar. Ecol. Prog. Ser. 66: 175-182. doi:10.3354/meps066175

Johnson, W. S., A. Gigon, S. L. Gulmon, and H. A. Mooney. 1974. Comparative photosynthetic capacities of intertidal algae under exposed and submerged conditions.

Jueterbock, A., L. Tyberghein, H. Verbruggen, J. A. Coyer, J. L. Olsen, and G. Hoarau. 2013. Climate change impact on seaweed meadow distribution in the North Atlantic rocky intertidal. Ecol. Evol. 3: 1356-1373. doi:10.1002/ece3.541

Kemp, W. M., and J. M. Testa. 2011. Metabolic balance between ecosystem production and consumption, p. 83-118. In Treatise on estuarine and coastal science. E. Wolanski, D.S. McLusky.

Lamote, M., L. E. Johnson, and Y. Lemoine. 2012. Photosynthetic responses of an intertidal alga to emersion: The interplay of intertidal height and meteorological conditions. J. Exp. Mar. Biol. Ecol. 428: 16-23. doi:10.1016/j.jembe.2012.05.021

Long, M. H., P. Berg, D. de Beer, and J. C. Zieman. 2015. In situ coral reef oxygen metabolism: an eddy correlation study. PLoS ONE 8: e58581. doi:10.1371/journal.pone.0058581

Lewis, E., D. Wallace, and L. J. Allison. 1998. Program developed for $\mathrm{CO}_{2}$ system calculations, Carbon Dioxide Information Analysis Center, managed by Lockheed Martin Energy Research Corporation for the US Department of Energy Tennessee.

López-Urrutia, Á., E. San Martin, R. P. Harris, and X. Irigoien. 2006. Scaling the metabolic balance of the oceans. Proc. Natl. Acad. Sci. 103: 8739-8744. 
Lüning, K. 1990. Seaweeds: Their environment, biogeography, and ecophysiology, John Wiley \& Sons.

Maberly, S. C., and T. V. Madsen. 1990. Contribution of air and water to the carbon balance of Fucus spiralis. Mar. Ecol. Prog. Ser. 62: 175-183. doi:10.3354/meps062175

Madsen, T.V., and S. C. Maberly. 1990. A comparison of air and water as environments for photosynthesis by the intertidal alga Fucus spiralis (Phaeophyta). J. Phycol. 26: 24-30. doi:10.1111/j.0022-3646.1990.00024.X

Mann, K. H. 1973. Seaweeds: their productivity and strategy for growth. Science 182: 975981. doi:10.2307/1737803

Mehrbach, C., C. H. Culberson, J. E. Hawley, and R. M. Pytkowicz. 1973. Measurement of the apparent dissociation constants of carbonic acid in seawater at atmospheric pressure. Limnol. Oceanogr. 18: 897-907. doi:10.4319/lo.1973.18.6.0897

Middelboe, A. L., K. Sand-Jensen, and T. Binzer. 2006. Highly predictable photosynthetic production in natural macroalgal communities from incoming and absorbed light. Oecologia 150: 464-476. doi:10.1007/s00442-006-0526-9

Migné, A., D. Davoult, N. Spilmont, D. Menu, G. Boucher, J.-P. Gattuso, and H. Rybarczyk. 2002. A closed-chamber $\mathrm{CO}_{2}$-flux method for estimating intertidal primary production and respiration under emersed conditions. Mar. Biol. 140: 865-869. doi:10.1007/s00227-001-0741-1

Migné, A., G. Delebecq, D. Davoult, N. Spilmont, D. Menu, and F. Gévaert. 2015a. Photosynthetic activity and productivity of intertidal macroalgae: In situ measurements, from thallus to community scale. Aquat. Bot. 123: 6-12. doi:10.1016/j.aquabot.2015.01.005

Migné, A., C. Golléty, and D. Davoult. 2015b. Effect of canopy removal on a rocky shore community metabolism and structure. Mar. Biol. 162: 449-457. doi:10.1007/s00227$014-2592-6$

Ouisse, V., A. Migné, and D. Davoult. 2011. Community-level carbon flux variability over a tidal cycle in Zostera marina and Z. noltii beds. Mar. Ecol. Prog. Ser. 437: 79-87. doi:10.3354/meps09274

Pedersen, O., T. D. Colmer, and K. Sand-Jensen. 2013. Underwater photosynthesis of submerged plants - Recent advances and methods. Front. Plant Sci. 4. doi:10.3389/fpls.2013.00140 
Quadir, A., P. J. Harrison, and R. E. DeWreede. 1979. The effects of emergence and submergence on the photosynthesis and respiration of marine macrophytes. Phycologia 18: 83-88. doi:10.2216/i0031-8884-18-1-83.1

R Core Team. 2015. R: A Language and Environment for Statistical Computing, R Foundation for Statistical Computing.

Raffaelli, D. G., and S. J. Hawkins. 1999. Intertidal ecology. Kluwer Academic Publishers, Dordrech.

Rheuban, J., P. Berg, and K. McGlathery. 2014. Multiple timescale processes drive ecosystem metabolism in eelgrass (Zostera marina) meadows. Mar. Ecol. Prog. Ser. 507: 1-13. doi:10.3354/meps 10843

Saha, M., and M. Wahl. 2013. Seasonal variation in the antifouling defence of the temperate brown alga Fucus vesiculosus. Biofouling 29: 661-668. doi:10.1080/08927014.2013.795953

Schmidt, A., M. Coll, T. Romanuk, and H. Lotze. 2011. Ecosystem structure and services in eelgrass Zostera marina and rockweed Ascophyllum nodosum habitats. Mar. Ecol. Prog. Ser. 437: 51-68. doi:10.3354/meps09276

Schubert, H., S. Sagert, and R. M. Forster. 2001. Evaluation of the different levels of variability in the underwater light field of a shallow estuary. Helgol. Mar. Res. 55: 12 22. doi:10.1007/s101520000064

Stratil, S. B., S. C. Neulinger, H. Knecht, A. K. Friedrichs, and M. Wahl. 2013. Temperaturedriven shifts in the epibiotic bacterial community composition of the brown macroalga Fucus vesiculosus. MicrobiologyOpen 2: 338-349. doi:10.1002/mbo3.79

Tait, L. W., I. Hawes, and D. R. Schiel. 2014. Shining light on benthic macroalgae: mechanisms of complementarity in layered macroalgal assemblages. PLoS ONE 9: e114146. doi:10.1371/journal.pone.0114146

Tait, L. W., and D. R. Schiel. 2010. Primary productivity of intertidal macroalgal assemblages: comparison of laboratory and in situ photorespirometry. Mar. Ecol. Prog. Ser. 416: 115-125. doi:10.3354/meps08781

Tait, L. W., and D. R. Schiel. 2011. Dynamics of productivity in naturally structured macroalgal assemblages: importance of canopy structure on light-use efficiency. Mar. Ecol. Prog. Ser. 421: 97-107. doi:10.3354/meps08909 
Tait, L. W., and D. R. Schiel. 2013. Impacts of temperature on primary productivity and respiration in naturally structured macroalgal assemblages. PLoS ONE 8: e74413. doi:10.1371/journal.pone.0074413

Tomanek, L., and B. Helmuth. 2002. Physiological ecology of rocky intertidal organisms: a synergy of concepts. Integr. Comp. Biol. 42: 771-775. doi:10.1093/icb/42.4.771

Wahl, M. 2009. Marine hard bottom communities: patterns, dynamics, diversity, and change. Springer Science \& Business Media, Berlin.

Wahl, M., V. Jormalainen, B. K. Eriksson, and others. 2011. Stress ecology in Fucus: Abiotic, biotic and genetic interactions, p. 37-105. In Advances in Marine Biology. Elsevier.

Webb, W. L., M. Newton, and D. Starr. 1974. Carbon dioxide exchange of Alnus rubra. Oecologia 17: 281-291. doi:10.1007/BF00345747

Williams, S. L., and M. N. Dethier. 2005. High and dry: Variation in net photosynthesis of the intertidal seaweed Fucus gardneri. Ecology 86: 2373-2379. doi:10.2307/3451026

Wyatt, K. H., A. R. Rober, N. Schmidt, and I. R. Davison. 2014. Effects of desiccation and rewetting on the release and decomposition of dissolved organic carbon from benthic macroalgae. Freshw. Biol. 59: 407-416. doi:10.1111/fwb.12273

Wyatt, K. H., R. J. Stevenson, and M. R. Turetsky. 2010. The importance of nutrient colimitation in regulating algal community composition, productivity and algal-derived DOC in an oligotrophic marsh in interior Alaska. Freshw. Biol. 55: 1845-1860. doi:10.1111/j.1365-2427.2010.02419.x

\section{AKNOWLEDGMENTS}

The authors thank the Marine Operations Department (Service Mer et Observation) at the Station Biologique de Roscoff for logistical support, and especially its three famous scubadivers, Mathieu Camusat, Yann Fontana and Wilfried Thomas. Thanks are also due to the SOMLIT network (Service d'Observation en Milieu LITtoral, INSU-CNRS) for providing incident irradiance and air and seawater temperature measurements, and to the students who helped in the field. This work benefited from the support of the Brittany Regional Council and the French National Research Agency through the Investments for the Future program IDEALG ANR-10-BTBR. 

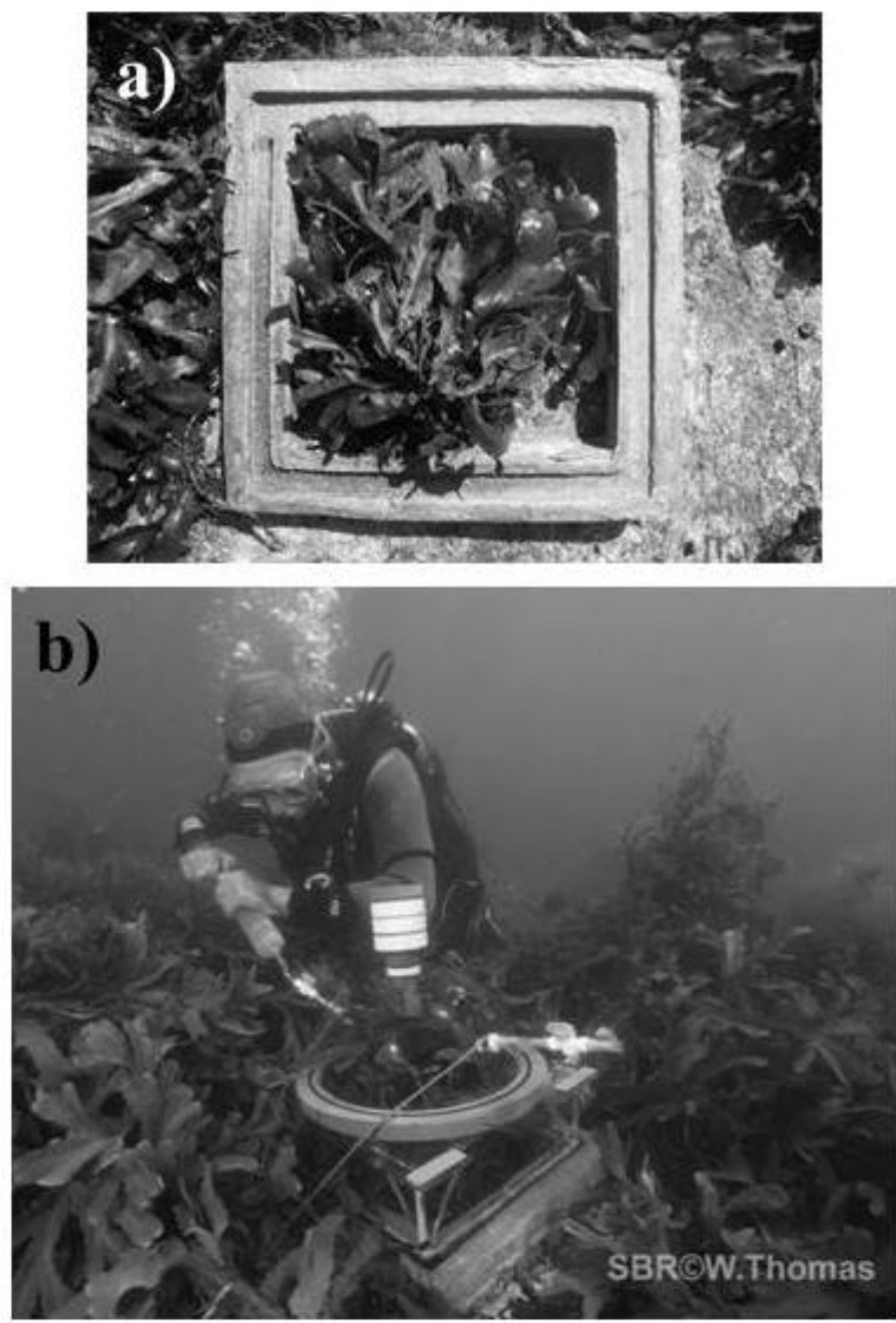

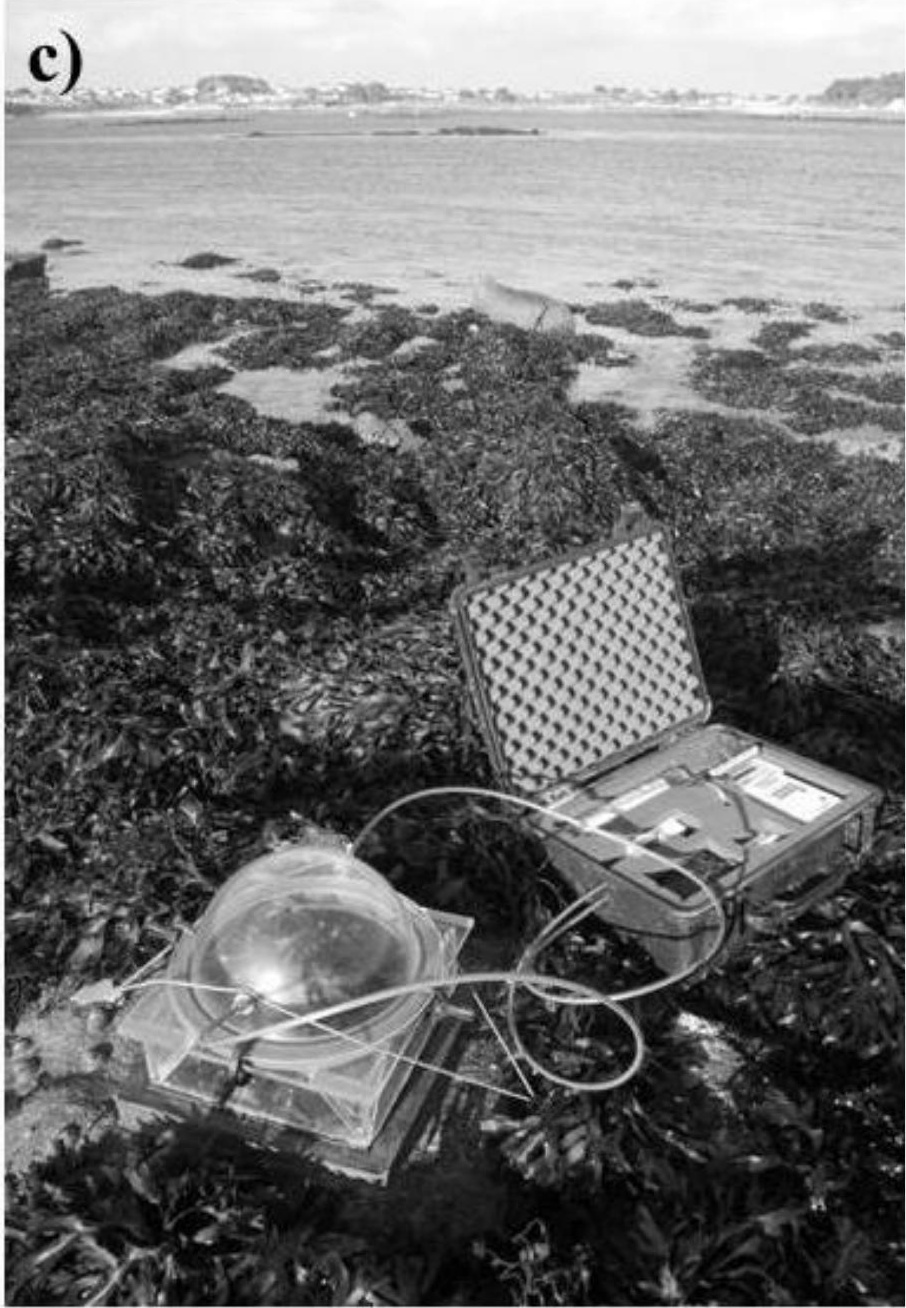

638

639 Figure 1: a) Concrete quadrat. b) Incubation in ambient light during an immersion period. c)

640 Incubation in ambient light during an emersion period. 

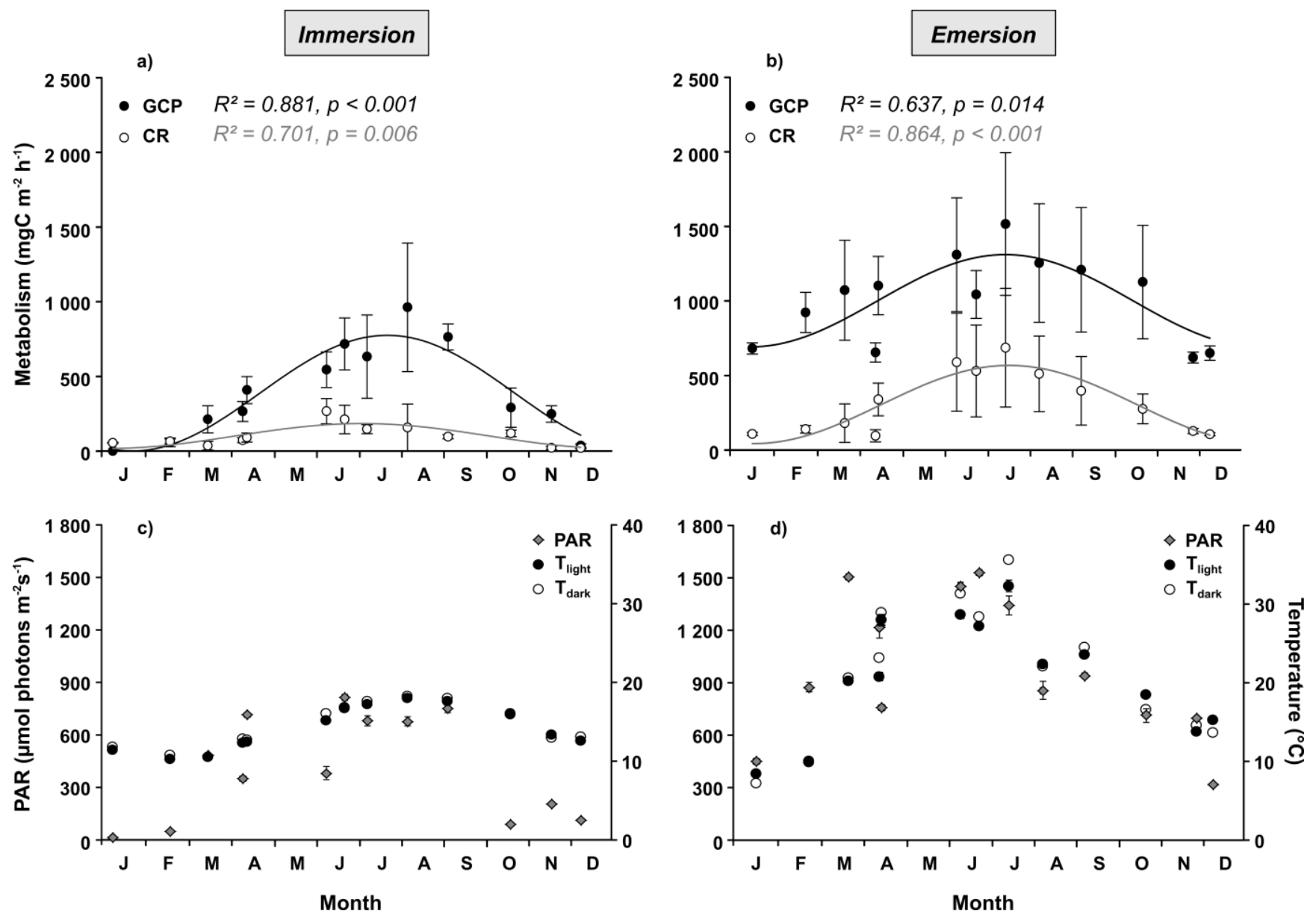

642 Figure 2: Mean ( \pm SE) gross community production (GCP) and community respiration (CR),

643 both expressed in $\mathrm{mg} \mathrm{C} \mathrm{m}^{-2} \mathrm{~h}^{-1}$, as a function of time, both during immersion (a) and emersion

644 (b). Black and gray lines represent the sinusoidal curves fitted on the GCP and CR datasets,

645 respectively. Mean $( \pm \mathrm{SE})$ irradiance $\left(\mathrm{PAR}\right.$, in $\mu \mathrm{mol}$ photons $\left.\mathrm{m}^{-2} \mathrm{~s}^{-1}\right)$, temperature $\left(\mathrm{T}_{\text {light }}\right.$, in

$\left.646{ }^{\circ} \mathrm{C}\right)$ during incubations in light and temperature $\left(\mathrm{T}_{\mathrm{dark}}\right.$, in $\left.{ }^{\circ} \mathrm{C}\right)$ during incubations in the dark,

647 are also indicated for both immersion (c) and emersion (d). 


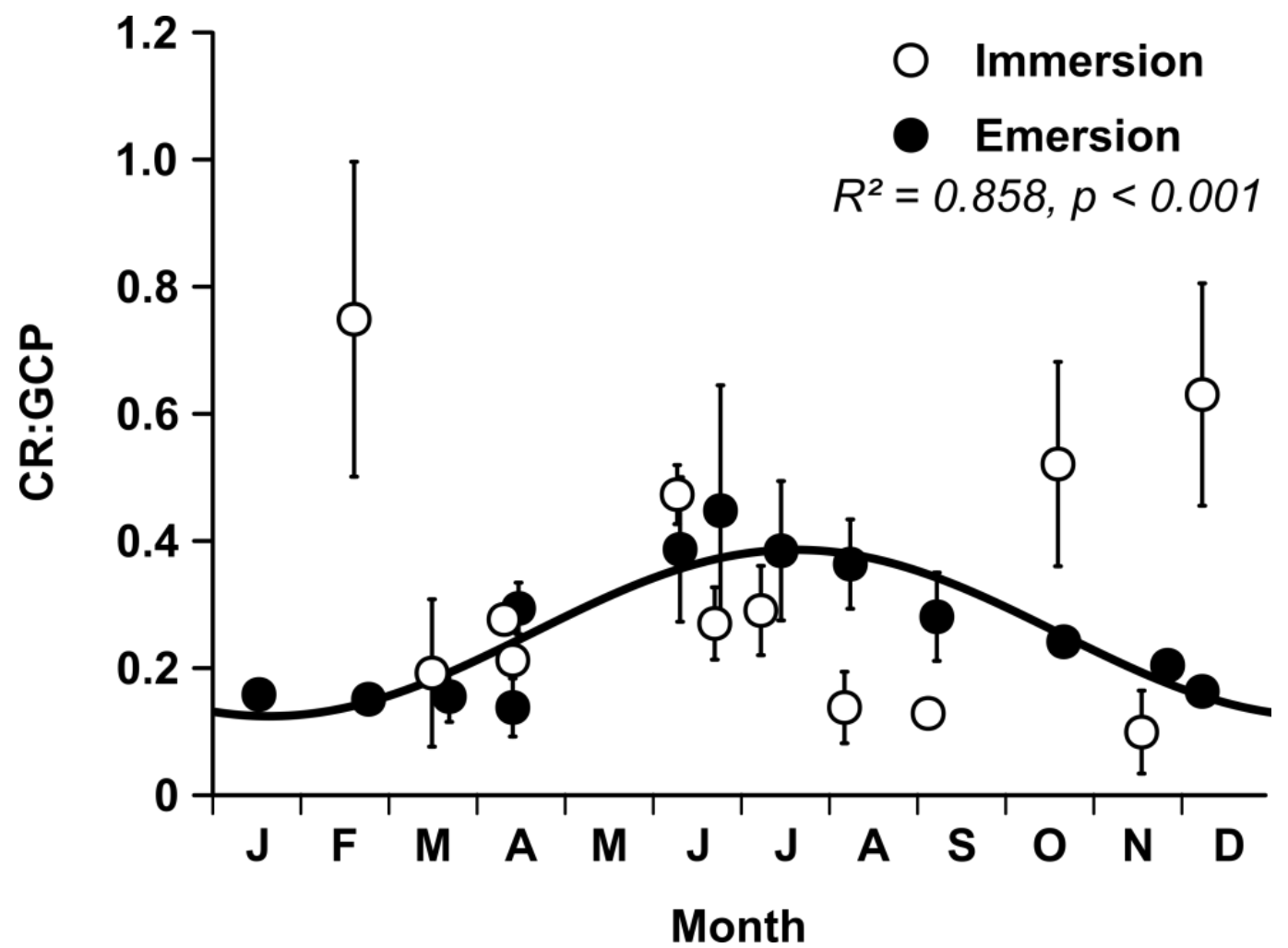

648

649 Figure 3: Mean $( \pm \mathrm{SE})$ community respiration $(\mathrm{CR})$ to gross community production $(\mathrm{GCP})$, 650 during a calendar year for both immersion and emersion. The black line represents the 651 sinusoidal curve fitted on metabolic balance measured during emersion. 


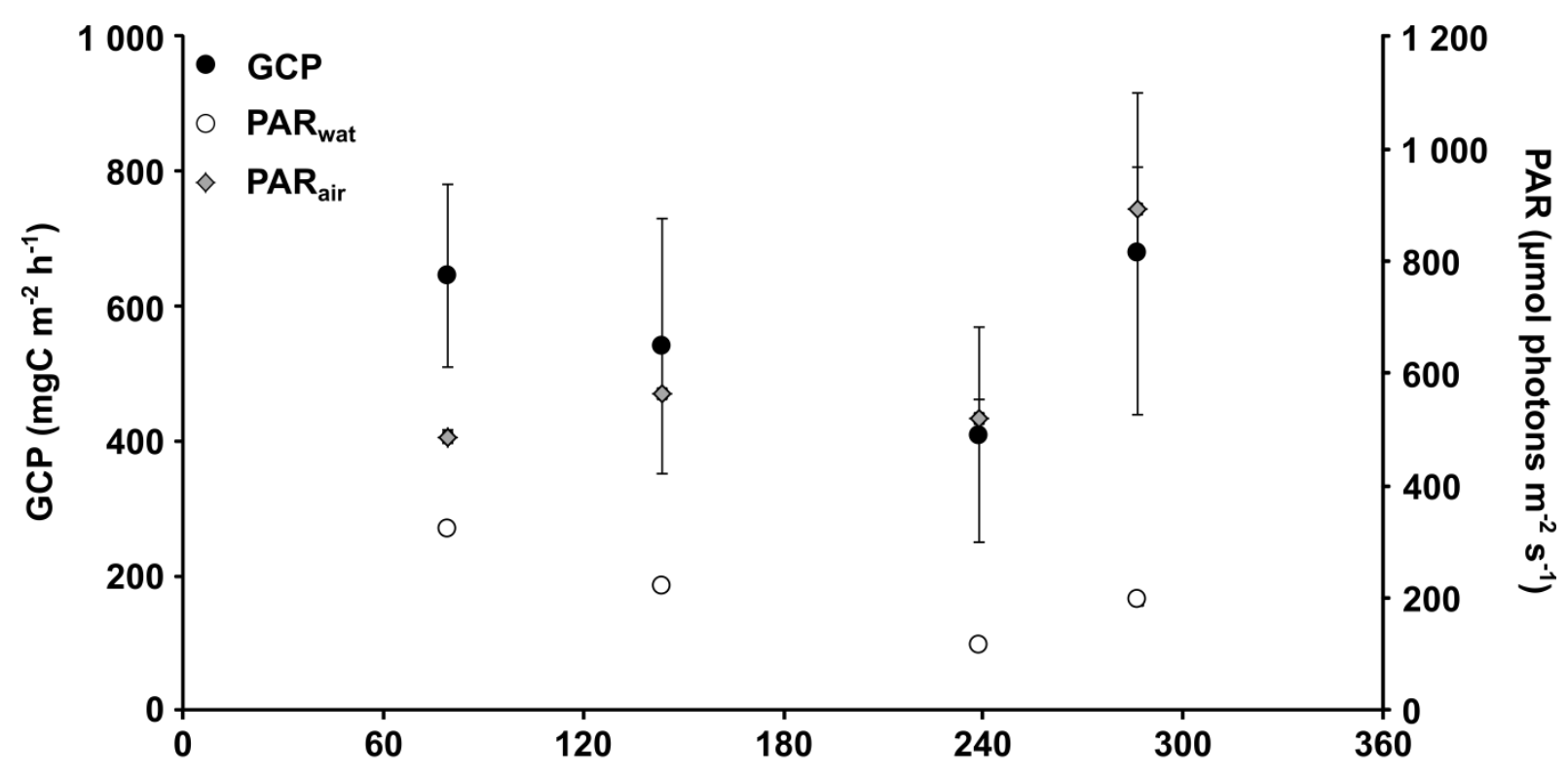

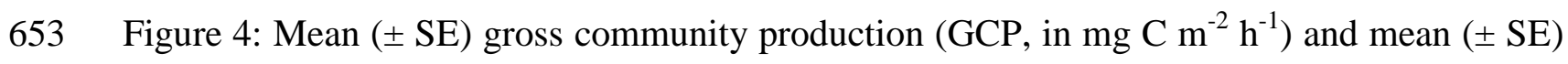
654 incident irradiance in the air $\left(\mathrm{PAR}_{\mathrm{air}}\right.$, in $\mu \mathrm{mol}$ photons $\left.\mathrm{m}^{-2} \mathrm{~s}^{-1}\right)$ and underwater $\left(\mathrm{PAR}_{\mathrm{wat}}\right.$, in $655 \mu$ mol photons $\mathrm{m}^{-2} \mathrm{~s}^{-1}$ ) during the underwater incubation series. Time indicates the length of 656 time (in minutes) since the flood tide first immersed the quadrats. Surface irradiance was 657 provided by the SOMLIT network, and was measured on the roof of the Station Biologique de 658 Roscoff. 


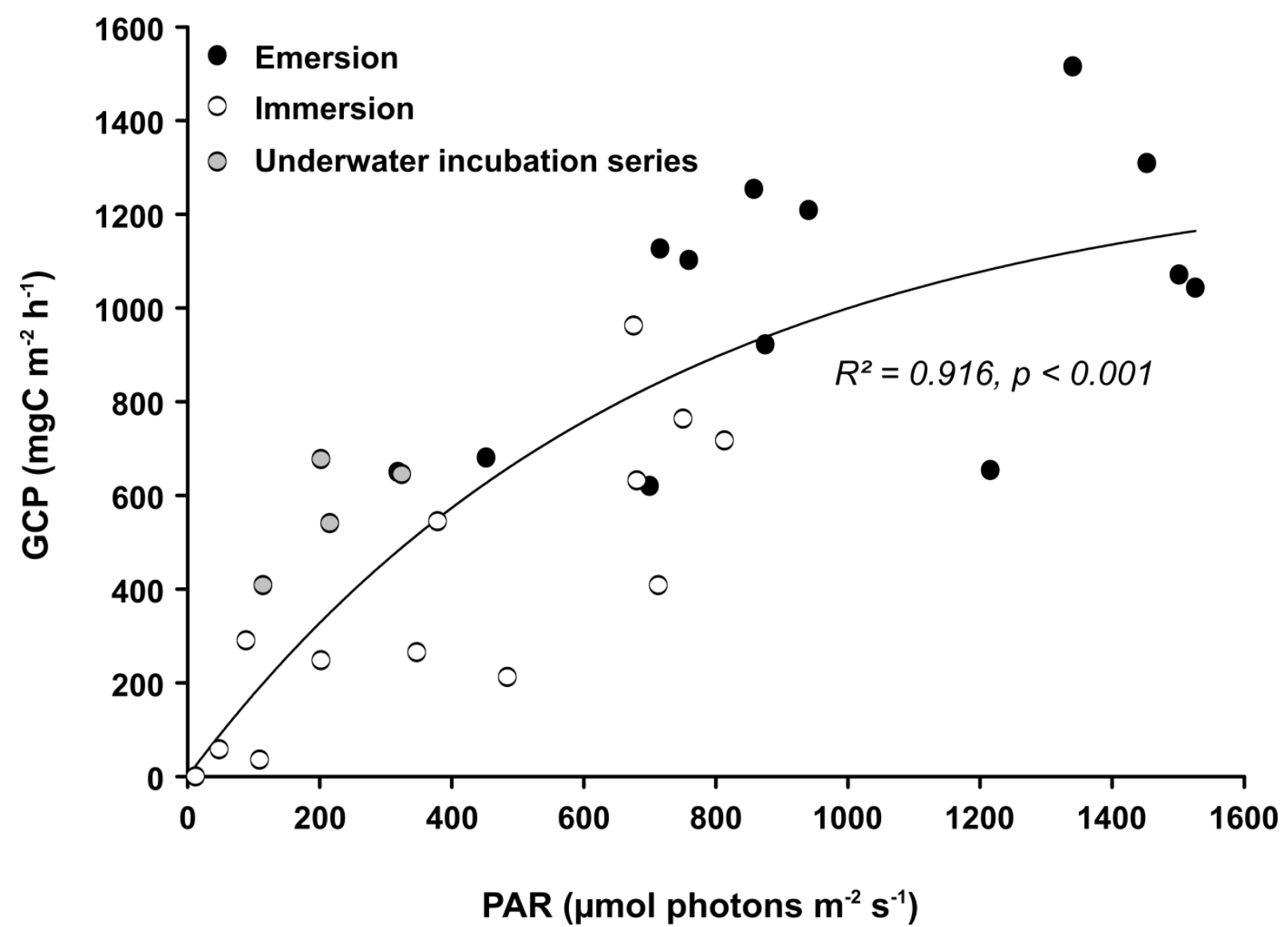

659

Figure 5: Relationship between gross community production (GCP, in $\mathrm{mg} \mathrm{C} \mathrm{m}^{-2} \mathrm{~h}^{-1}$ ) and 661 irradiance (PAR, in $\mu$ mol photons $\mathrm{m}^{-2} \mathrm{~s}^{-1}$ ), established from the values obtained during 662 emersion and immersion and from underwater incubation series, and according to the 663 mathematical model of Webb et al. (1974) (black line).

664 


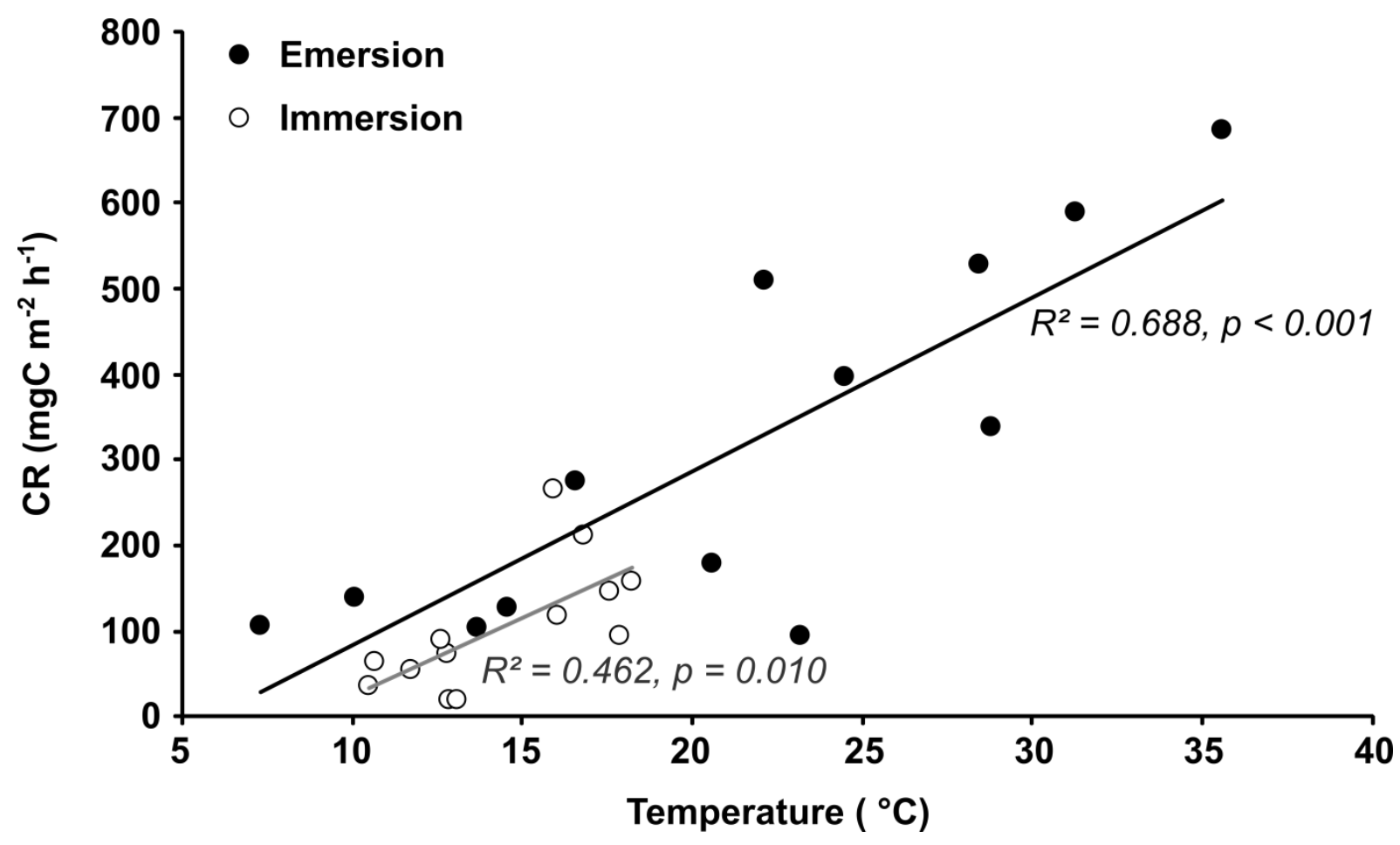

665

666 Figure 6: Linear relationships between community respiration (CR, in $\mathrm{mg} \mathrm{C} \mathrm{m} \mathrm{m}^{-1}$ ) and 667 temperature $\left({ }^{\circ} \mathrm{C}\right)$, established from the values obtained either during emersion (black line) or 668 during immersion (gray line). 

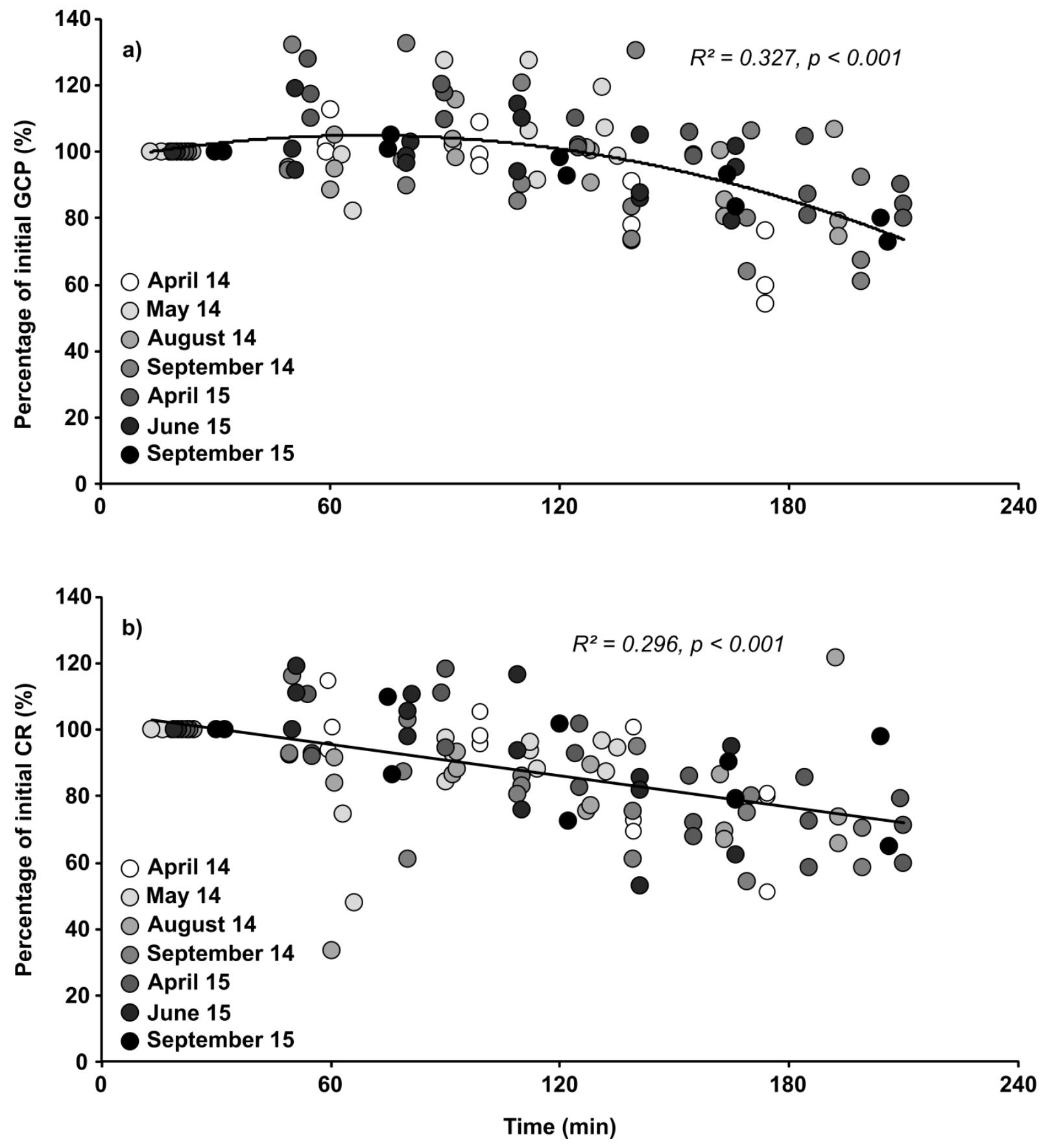

669

670 Figure 7: Fluctuations in gross community production (a) and community respiration (b)

671 during the aerial incubation series, at different moments during the 2014-2015 study years,

672 from the beginning of aerial exposure to the return of seawater with the flood tide. 
673 Table 1: Sinusoidal curve parameters (n, a, b, c, $\mathrm{R}^{2}$ and $p$ ) for Fucus serratus community 674 respiration (CR), gross production (GCP) and CR:GCP ratio, during immersion and emersion.

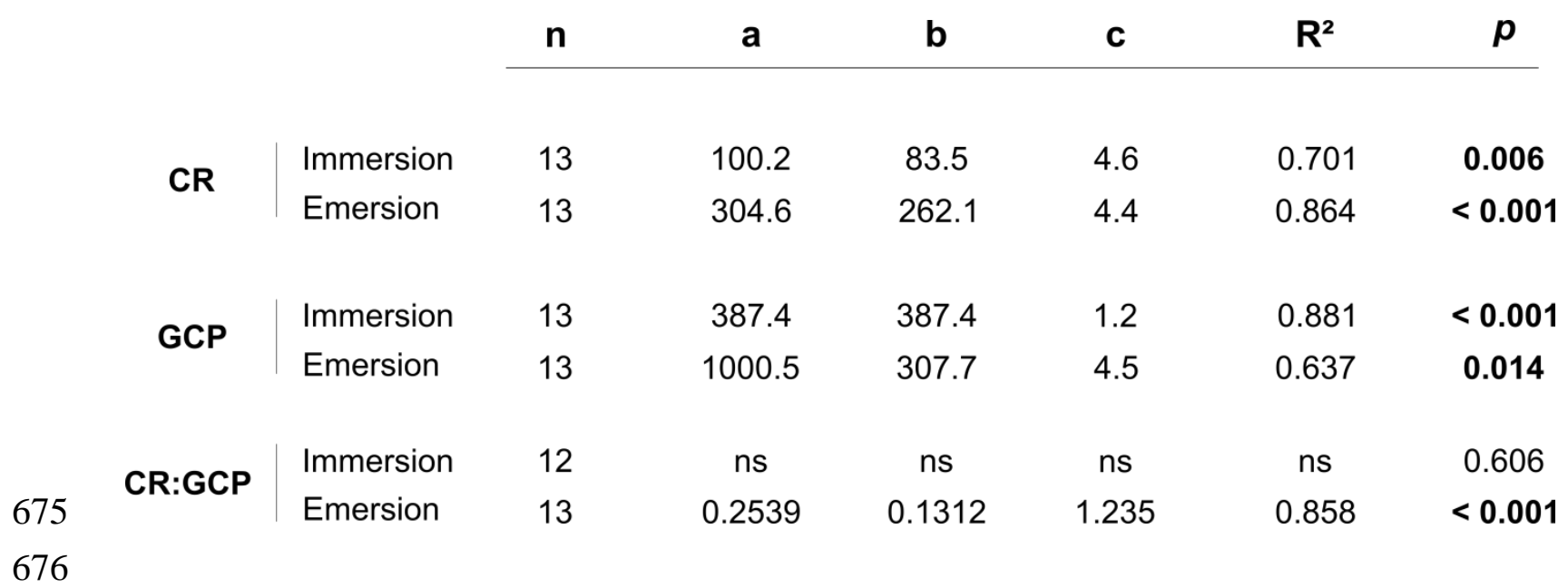


677 Table 2: Wilcoxon signed rank test results $(\mathrm{V}, p)$ for differences between emersion and 678 immersion, for mean community respiration (CR), gross community production (GCP), 679 CR:GCP ratio, irradiance (PAR) and temperature during dark and light incubations ( $\mathrm{T}_{\mathrm{CR}}$ and $680 \mathrm{~T}_{\mathrm{GCP}}$, respectively).

\begin{tabular}{lcc} 
& V & $p$ \\
\cline { 2 - 3 } CR & 91 & $<\mathbf{0 . 0 0 1}$ \\
GCP & 91 & $<\mathbf{0 . 0 0 1}$ \\
CR:GCP & 37 & 0.910 \\
PAR & 91 & $<\mathbf{0 . 0 0 1}$ \\
T $_{\text {CR }}$ & 82 & $\mathbf{0 . 0 0 8}$ \\
T $_{\text {GCP }}$ & 85 & $\mathbf{0 . 0 0 3}$
\end{tabular}




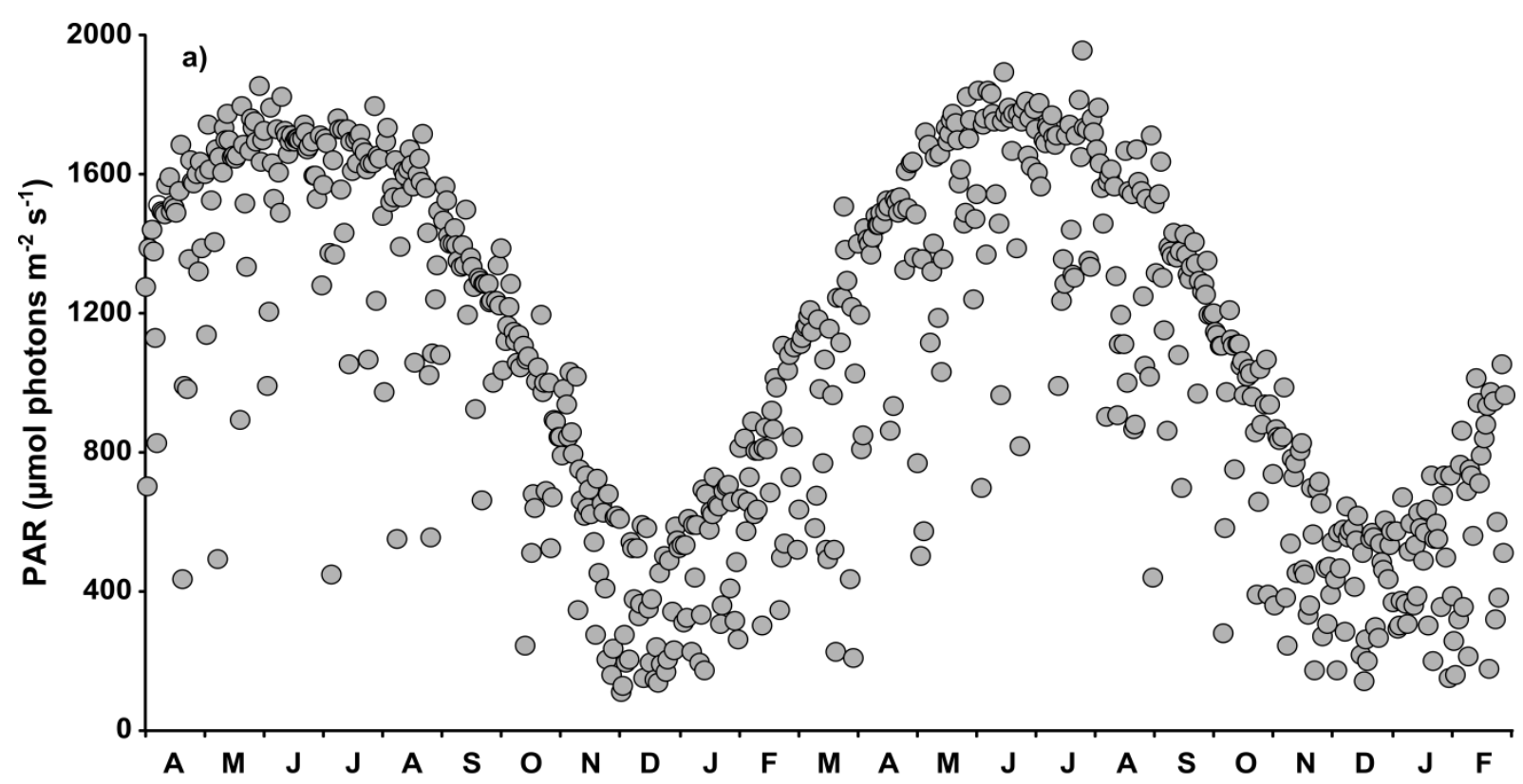

682

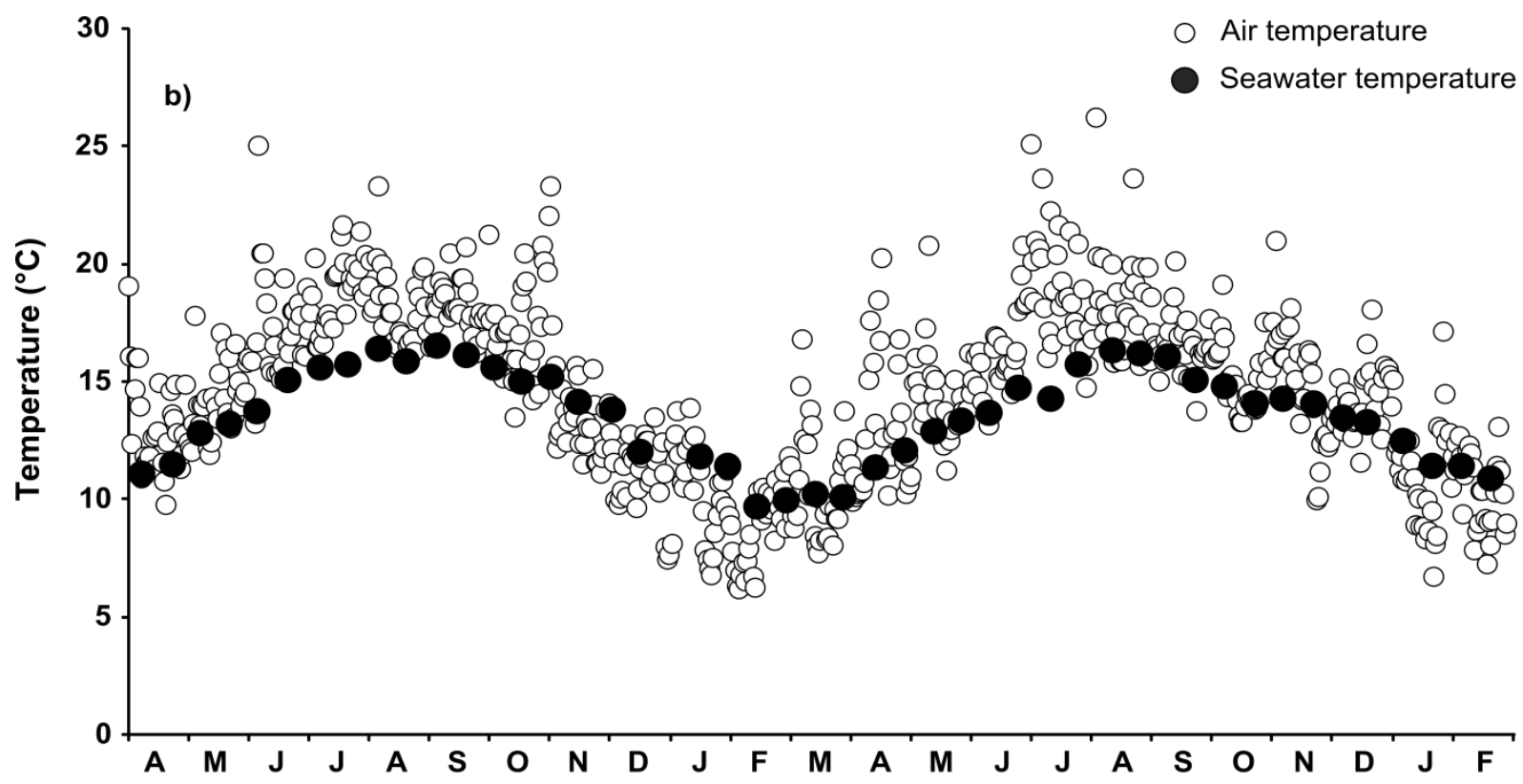

683

Months

684 Supplementary material 1: (a) Daily maximal irradiance in air (PAR, 400-700 nm, $\mu$ mol 685 photons $\mathrm{m}^{-2} \mathrm{~s}^{-1}$ ) in Roscoff, as a function of time from April 2014 to February 2016. (b)

686 Seawater temperature and daily maximal temperature in air in Roscoff, both expressed in ${ }^{\circ} \mathrm{C}$ 687 during the study period from April 2014 to February 2016. Datasets come from the SOMLIT 688 Network and are available at http://somlit-db.epoc.u-bordeaux1.fr/bdd.php?serie=ST. 


\begin{tabular}{|c|c|c|c|c|c|c|c|c|c|c|c|c|c|c|}
\hline & Taxa & Apr-14 & Jun-14 (1) & Jun-14 (2) & Jul-14 & Aug-14 & Sep-14 & Oct-14 & Nov-14 & Mar-15 & Apr-15 & Dec-15 & Jan-16 & Feb-16 \\
\hline & Fucus serratus & 100 & 100 & 100 & 100 & 100 & 100 & 100 & 100 & 100 & 100 & 100 & 100 & 100 \\
\hline & Fucus sp. (juveniles) & 67 & 100 & 67 & 33 & 100 & 100 & 100 & 100 & 100 & 100 & 100 & 100 & 100 \\
\hline & Chondracanthus acicularis & 0 & 0 & 0 & 33 & 33 & 33 & 33 & 33 & 0 & 0 & 67 & 33 & 33 \\
\hline & Cladophora rupestris & 67 & 67 & 67 & 67 & 67 & 67 & 67 & 67 & 100 & 67 & 100 & 100 & 100 \\
\hline & Ectocarpales & 0 & 0 & 0 & 33 & 67 & 33 & 0 & 33 & 33 & 33 & 0 & 0 & 0 \\
\hline Primary & Hildenbrandia rubra & 67 & 100 & 100 & 100 & 100 & 100 & 100 & 100 & 67 & 100 & 67 & 100 & 100 \\
\hline producers & Lomentaria articulata & 0 & 0 & 0 & 0 & 0 & 0 & 0 & 0 & 0 & 33 & 0 & 67 & 67 \\
\hline & Mastocarpus stellatus & 100 & 100 & 100 & 100 & 100 & 100 & 100 & 100 & 100 & 100 & 100 & 100 & 100 \\
\hline & Phymatholithon lenormandii & 100 & 100 & 100 & 100 & 100 & 100 & 100 & 100 & 100 & 33 & 100 & 100 & 100 \\
\hline & Porphyra sp. & 0 & 33 & 0 & 33 & 0 & 33 & 0 & 0 & 0 & 0 & 0 & 0 & 0 \\
\hline & Ulva sp.1 (tubular species) & 0 & 67 & 67 & 100 & 100 & 100 & 100 & 100 & 67 & 67 & 33 & 0 & 0 \\
\hline & Ulva sp.2 (foliose species) & 0 & 33 & 0 & 67 & 33 & 100 & 100 & 67 & 100 & 100 & 33 & 33 & 67 \\
\hline & Other Rhodophyta & 0 & 0 & 33 & 33 & 33 & 0 & 67 & 0 & 0 & 67 & 0 & 33 & 67 \\
\hline & Alcyonidium sp. & 33 & 0 & 0 & 0 & 0 & 0 & 0 & 0 & 0 & 33 & 100 & 100 & 67 \\
\hline & Amphipods & 0 & 0 & 0 & 33 & 67 & 33 & 33 & 0 & 33 & 0 & 33 & 0 & 67 \\
\hline & Campanulariidae & 0 & 0 & 0 & 0 & 67 & 67 & 33 & 0 & 0 & 0 & 33 & 33 & 0 \\
\hline & Dynamena pumila & 0 & 67 & 33 & 33 & 67 & 67 & 0 & 0 & 0 & 67 & 0 & 33 & 0 \\
\hline Macrofauna & Electra pilosa & 0 & 0 & 0 & 0 & 0 & 33 & 0 & 0 & 0 & 0 & 100 & 33 & 0 \\
\hline & Flustrellidra hispida & 100 & 67 & 33 & 67 & 67 & 100 & 100 & 67 & 67 & 33 & 100 & 100 & 100 \\
\hline & Polyclinidae & 0 & 0 & 0 & 67 & 0 & 0 & 0 & 0 & 0 & 33 & 33 & 0 & 0 \\
\hline & Schizoporella unicornis & 0 & 0 & 0 & 0 & 0 & 0 & 33 & 0 & 0 & 0 & 100 & 100 & 100 \\
\hline & Spirorbis sp. & 100 & 100 & 100 & 100 & 100 & 100 & 100 & 100 & 67 & 100 & 100 & 100 & 100 \\
\hline
\end{tabular}




\begin{tabular}{|c|c|c|c|c|c|c|c|c|c|c|c|c|c|}
\hline Taxa & Apr-14 & Jun-14 (1) & Jun-14 (2) & Jul-14 & Aug-14 & Sep-14 & Oct-14 & Nov-14 & Mar-15 & Apr-15 & Dec-15 & Jan-16 & Feb-16 \\
\hline Actinia equina & 0 & 0 & 0 & 0 & 0 & 0 & 0 & 0 & 0 & 1 & 0 & 0 & 0 \\
\hline Anemonia viridis & 0 & 0 & 0 & 0 & 0 & 0 & 1 & 1 & 1 & 0 & 0 & 0 & 0 \\
\hline Cirripedia & 0 & 0 & 0 & 0 & 0 & 0 & 0 & 1 & 0 & 0 & 0 & 0 & 0 \\
\hline Decapoda & 0 & 0 & 1 & 0 & 0 & 0 & 0 & 1 & 0 & 0 & 1 & 0 & 0 \\
\hline Dynamene bidentata & 0 & 0 & 0 & 2 & 1 & 2 & 2 & 1 & 2 & 1 & 1 & 1 & 2 \\
\hline Gibbula pennanti & 8 & 7 & 8 & 5 & 8 & 6 & 5 & 8 & 5 & 10 & 2 & 1 & 1 \\
\hline Gibbula umbilicalis & 0 & 2 & 1 & 2 & 1 & 3 & 3 & 3 & 3 & 4 & 1 & 1 & 2 \\
\hline Idotea sp. & 1 & 0 & 0 & 0 & 1 & 1 & 1 & 0 & 0 & 0 & 0 & 0 & 1 \\
\hline Littorina obtusata & 4 & 4 & 6 & 18 & 9 & 9 & 8 & 7 & 3 & 2 & 5 & 2 & 7 \\
\hline Nucella lapillus & 0 & 0 & 0 & 0 & 0 & 0 & 0 & 0 & 0 & 0 & 1 & 1 & 0 \\
\hline Patella pellucida & 0 & 0 & 0 & 0 & 0 & 1 & 0 & 0 & 0 & 0 & 0 & 0 & 0 \\
\hline Patella vulgata & 0 & 0 & 0 & 0 & 0 & 0 & 0 & 1 & 1 & 1 & 5 & 5 & 4 \\
\hline Spirobranchus triqueter & 0 & 0 & 0 & 0 & 0 & 0 & 0 & 1 & 0 & 1 & 0 & 1 & 0 \\
\hline Tricolia pullus & 0 & 1 & 0 & 0 & 0 & 1 & 1 & 0 & 1 & 1 & 0 & 1 & 0 \\
\hline
\end{tabular}

